\title{
Pemanfaatan Limbah Gula untuk Pembuatan Etanol yang Dipengaruhi oleh Komposisi Khamir pada Proses Fermentasi
}

\author{
Sinar Perbawani Abrina Anggraini 1), Susy Yuniningsih 2) \\ 1,2 Program Studi Teknik Kimia, 1,2, Fakultas Teknik, \\ 1,2 Universitas Tribhuwana Tunggadewi \\ e-mail corresponding author : spabrina74@gmail.com
}

\begin{abstract}
ABSTRAK
Peningkatan kebutuhan masyarakat yang tidak seimbang dengan persediaan BBM ditingkat nasional dan dunia memunculkan dampak krisis energi. Ketergantungan hanya pada energi energi yang tidak bisa diperbaharui membuat manusia harus mencari sumber energi alternatif. Bioetanol merupakan salah satu jenis bahan bakar yang dapat menggantikan BBM. Proses bioethanol dilakukan secara fermentasi dari bahan biomassa dengan bantuan mikroorganisme. Tujuan penelitian ini adalah mengetahui kinerja komposisi khamir pada proses fermentasi terhadap kualitas etanol. Bahan yang digunakan yaitu limbah gula berupa molases dengan kadar gula 54\% sebanyak $8 \mathrm{~L}$. Molases dicampur dengan NPK, Urea dan Khamir Saccharomyces Cerevisiae. Komposisi khamir divariasikan sebesar 8, 12, 16, 20, 24, 28 dan 32 gram. Untuk uji kadar etanol pada tiap variable dengan mengukur perbedaan densitas air dan etanol dengan menggunakan alat piknometer. Hasil dari penelitian ini adalah kualitas etanol tertinggi didapatkan pada konsentrasi gula 12 gram (0,2\%), sebesar 5,6\%. Kualitas etanol terendah didapat pada konsentrasi gula 32 gram $(0,4 \%)$ yaitu 3,29\%, sedangkan pada komposisi khamir 8, 16, 20, 24, 28 gram kualitas etanol terus menurun berturut-turut menjadi 3,6\%, 5,4\%, $5,3 \%, 5,2 \%$ dan $5,1 \%$.
\end{abstract}

Kata-kata kunci : Fermentasi; Etanol; Molases; Khamir.

\begin{abstract}
The increasing needs of people who are not balanced with fuel supplies at the national and world level are bringing about the impact of the energy crisis. The reliance only on renewable energy makes people have to look for alternative energy sources. Bioethanol is a type of fuel that can replace fuel. The bioethanol process is fermented from biomass material with the help of microorganisms. The purpose of this study is to know the performance of khamir composition in fermentation process against ethanol quality. The ingredients used are molasses with a sugar content of $54 \%$ as much as $8 \mathrm{~L}$. Molasses is mixed with NPK, Urea and Khamir Saccharomyces Cerevisiae. Khamir's composition varies by 8, 12, 16, 20, 24, 28 and 32 grams. To test ethanol levels on each variable by measuring the difference in water density and ethanol using a piknometer. The result of this study is the highest ethanol quality obtained at a sugar concentration of 12 grams $(0.2 \%)$, at $5.6 \%$. The lowest ethanol quality is obtained at a sugar concentration of 32 grams $(0.4 \%)$ i.e. $3.29 \%$, while in khamir composition 8, 16, 20, 24, 28 grams of ethanol quality continued to decrease consecutively to 3.6\%, 5.4\%, $5.3 \%, 5.2 \%$ and $5.1 \%$.
\end{abstract}

Keywords : Fermentation; Ethanol; Molasses; Khamir

Cara mengutip : Anggraini, S.P.A., dan Yuniningsih, S. (2020). Pemanfaatan Limbah Gula untuk Pembuatan Etanol yang Dipengaruhi oleh Komposisi Khamir pada Proses Fermentasi. Reka Buana: Jurnal Ilmiah Teknik Sipil dan Teknik Kimia, 5(2), 171-177. http://dx.doi.org/10.33366/rekabuana.v5i2.1969 


\section{PENDAHULUAN}

Ketergantungan masyarakat saat ini pada kebutuhan BBM menjadi masalah, dimana persediaan yang tersedia tidak seimbang dengan kebutuhan masyarakat. Hal ini pula yang menjadi keresahan bagi Indonesia tentang adanya krisis energi. Pada Energi yang tersedia secara final termasuk biomassa terjadi peningkatan sebesar sebesar 2,91\% per tahun pada tahun 2012 dari tahun 2000 yaitu dari 764 juta setara barel minyak (SBM) menjadi 1.079 juta SBM. [1] Bioetanol merupakan salah satu solusi untuk memenuhi kebutuhan BBM bagi masyarakat selain aman bagi lingkungan karena berbahan dasar biomassa, sehingga layak jika bioetanol ini untuk dikembangkan sebagai energi alternatif. Hasil buangan dari BBM Bioetanol berupa $\mathrm{CO}_{2}$ yang aman pula bagi lingkungna [2]. Bioetanol merupa-kan bahan bakar yang memiliki oktan tinggi (118) dan memiliki efisiensi pembakaran sebesar 35\% oksigen dan aman bagi lingkungan karena emisi gas buangnya sangat rendah (19-25\%) seperti CO, NO dan gas yang lain [3]. Hal inilah yang menjadi potensi dari bioetanol sebagai bahan bakar alternatif cukup besar bagi pemerintah. Bioetanol pun juga dapat digunakan dalam kebutuhan hidup seharihari. Bioetanol selain bias sebagai bahan bakar bisa juga digunakan bahan obatobatan, campuran kimia, parfum maupun dalam kebutuhan memasak rumah tangga sebagai pengganti minyak tanah dan gas. Untuk memenuhi permintaan Negara dan masyarakat maka perlu adanya target untuk memproduksi etanol secara nasional sebesar 150 juta liter per tahun sehingga lapangan pekerjaan akan semakin meningkat [4]. Salah satu bahan pembuatan etanol yang berbahan sukrosa adalah molases. Pada proses pembuatan etanol, molases merupakan bahan dasar yang paling efektif karena langsung menggunakan fermentasi tanpa harus melalui proses liquifikasi dan sakarifikasi. Sedangkan yang berbahan dasar pati seperti sagu, ubi kayu, jagung, harus melalui proses liquifikasi dan sakarifikasi terlebih dahulu kemudian proses fermentasi. Tetapi untuk mengambil bahan berpati menrupakan hasil pertanian yang akan mengganggu kestabilan pangan sehingga tidak diperkenankan asalkan memang berupa limbah pertanian yang tidak akan digunakan pangan oleh masyarakat. Pada proses fermentasi yang berasal dari pati dianggap tidak efisien karena masih melakukan perlakukan awal terlebih dahulu untuk melepas lignin dalam bahan tersebut sehingga akan menghasilkan etanol [5]. Bioetanol yang berbahan molasses akan lebih efektif prosesnya jika dibandingkan dengan berbahan pati, karena hanya melalui proses fermentasi dan destilasi tanpa melalui proses liquifikasi dan sakarifikasi sehingga sangat berpotensi untuk ditingkatkan. Bahan produksi tebu menurut data statistic perkebunan Indonesia (2005) sebesar 1.702.311 ton, sehingga perkiraan akan menghasilkan 2,7\% molasses, secara nasional molasses akan menghasilkan 46.962,4 ton per tahun [6]. Faktor yang menentukan pembentukan etanol dari proses fermentasi salah satunya adalah pemberian komposisi starter yang sesuai. Jika jumlah starter terlalu sedikit maka kualitas etanol kurang optimal karena enzim pada khamir membutuhkan energi yang besar untuk merubah substrat menjadi ethanol. Sedangkan pada starter yang terlalu banyak maka kualitas ethanol 
menjadi lebih sedikit hasilnya karena antar khamir saling berkompetisi untuk memperoleh makanan/ sumber energy. Menurut Muhammad Rijal et.al, (2019) menyatakan bahwa pada konsentrasi ragi 1\% menghasilkan kadar bioetanol sebesar 0,26\% dengan volume $92,7 \mathrm{ml}$. Sedangkan, konsentrasi $4 \%$ menghasilkan kadar bioetanol sebesar $1,25 \%$ dan volume sebanyak 97,3 $\mathrm{ml}$ dan waktu fermentasi selama 6 hari [7]. Pada uraian diatas diketahui bahwa komposisi khamir (starter) dapat mempengaruhi hasil besarnya konsentrasi etanol. Sedangkan pada penelitian ini menggunakan khamir murni dan bukan berupa ragi, sehingga diharapkan menghasilkan kadar Etanol yang lebih tinggi. Tujuan penelitian ini adalah mengetahui kinerja komposisi khamir pada proses fermentasi terhadap kualitas etanol

\section{METODE PENELITIAN}

Proses fermentasi menggunakan jenis fermentasi sistem tertutup (batch culture), yaitu selama proses fermentasi berjalan tidak ada penambahan substrat. Alat utama yang digunakan adalah berupa tangki silinder yang disebut fermentor atau bioreaktor, berbahan stainlees bervolume 10 liter. Fermentor berguna untuk memfermentasikan molasses. Alat ini dilengkapi dengan pengaduk dan pengontrol suhu (termokopel). Fungsi dari pengaduk ini untuk mencampur substrat yang difermentasikan dan juga supaya pengendapan tidak terjadi, sehingga kualitas enzim dapat dihasilkan kadar ethanol lebih tinggi. Termokopel digunakan untuk menjaga suhu yang dikehendaki dalam proses fermentasi yaitu $32^{\circ} \mathrm{C}$ dan dilengkapi pula dengan jaket pendingin untuk menjaga suhu tetap stabil, sebab pada proses fermentasi molasses menjadi etil alkohol akan menghasilkan panas (eksotermal). Menurut Mulono Apriyanto et.al (2017) [8] menyatakan bahwa partum-buhan khamir Saccharomyces cerevisiae yang optimum yaitu pada suhu antara $30-35^{\circ} \mathrm{C}$.

Bahan baku yang digunakan adalah molasses dan khamir yaitu Saccharomyces cerevisiae. Dengan beberapa variasi khamir terhadap kadar ethanol. Pada proses pecampuran khamir, NPK dan urea dimasukkan ke dalam alat fermentor dengan penambahan molasses di dalamnya. Kemudian didiam-kan selama 3 hari (72 jam) selama proses fermentasi. dengan variasi khamir seba-nyak $(8,12,16,20,24,28$ dan 32) gram. Selesainya proses fermentasi dapat dilihat dari gelembung yang mulai berkurang pada botol buangan gas $\mathrm{CO}_{2}$. Setelah terjadi fermentasi, analisa kadar ethanol dilakukan menggunakan alkoholmeter

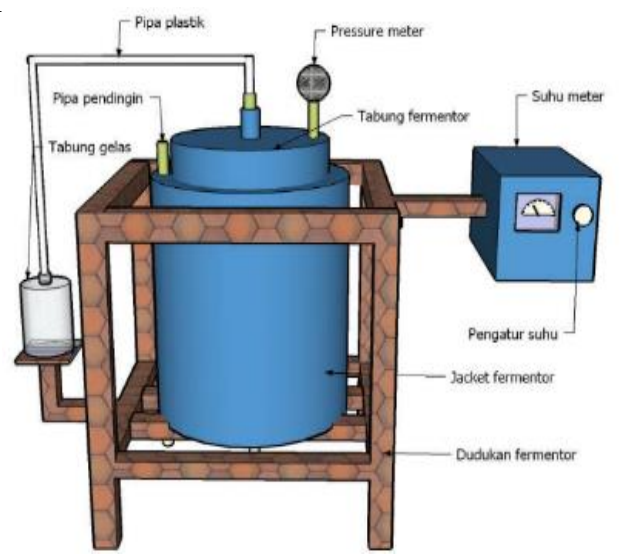

Gambar 1. Fermentor Tampak Luar 
Metode yang digunakan pada penelitian ini adalah metode Experimental Laboratories Parameter yang diamati adalah komposisi khamir dan kadar ethanol.

\section{HASIL DAN PEMBAHASAN}

Salah satu faktor yang mempengaruhi besarnya kadar etanol adalah komposisi Khamir pada proses fermentasi. Varibel berubah yang digunakan pada penelitian ini adalah komposisi khamir berupa ragi antara lain 8gr, 12gr, 16gr ,20gr ,24gr, 28gr, dan 32gr. Perbandingan campuran yang digunakan yaitu 1:3 dimana 2 liter molases dicampur dengan air 6 liter. Kadar glukosa yang terkandung pada molases yaitu sebesar $54 \%$. Alat uji analisa yang digunakan untuk mengetahui kadar etanol menggunakan piknometer. Hasil yang didapat di setiap komposisi khamir dapat dilihat pada

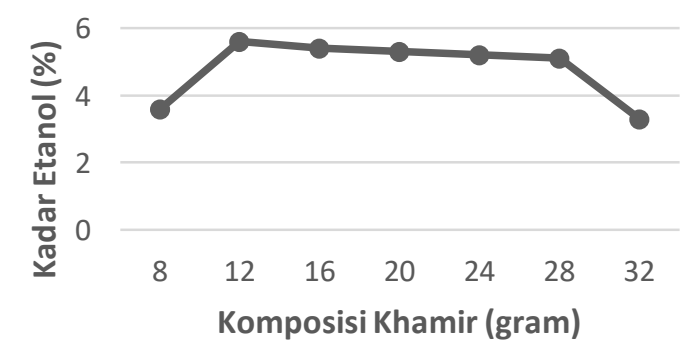

Gambar 2 dibawah ini.

Grafik 2. Perbandingan kadar etanol dan komposisi khamir 1:3

Pada perlakuan dengan komposisi khamir berupa ragi sebanyak 8 gr didapatkan kadar alkohol sebesar 3,6\%. Hal ini dikarenakan masih sedikitnya populasi khamir yang ada dalam proses fermentasi sehingga kandungan gula yang ada dalam fermentasi tersebut masih sedikit yang mengakibatkan alkohol yang dihasilkan pun tidak banyak. Selain itu juga aktivitas sel khamir belum cukup energi untuk memecah substrat sebagai kebutuhan energi untuk pertumbuhan metabolism menghasilkan etanol

Pada tahap ini tidak terjadi pemecahan glukosa sehingga perubahan potensial tidak terjadi antara proses oksidasi-reduksi sehingga energi yang terjadi sangat kecil. Menurut Yurliasni et.al (2013) menyatakan bahwa untuk menghasilkan etanol yang tinggi memerlukan energy yang besar dalam aktivitas sel khamir [8].

Pada kompoisis khamir 12 gr menghasilkan kadar etanol sebesar 5,6\%, hal ini dikarenakan sel khamir (Saccharomyces cereviseae ) mampu memecah glukosa melalui pertumbuhan dari sel dengan bantuan nutrient yang cukup sehingga menghasilkan kadar etanol yang lebih tinggi. Pertumbuhan dari khamir lebih sempurna dengan meningkatnya komposisi khamir sehingga Saccharomyces cereviseae akan tumbuh lebih maksimal dengan mencerna nutrient yang diberikan

Hal ini sesuai dengan hasil penelitian Desnilawati Hotmaria Simanjuntak, et al (2016) bahwa terjadi proses fermentasi dengan adanya pemecahan pada glukosa menjadi etanol dan karbon dioksida yang diakibatkan oleh aktivitas dari khami [9]. Pada proses fermentasi terjadi reaksi sebagai berikut :

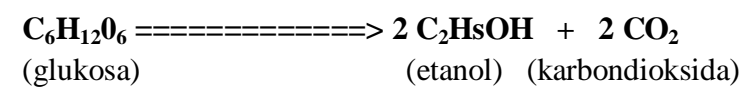

Jika dilihat pada Gambar 3 diatas terjadi penurunan kadar alkohol hingga akhir variable. Pada sampel dengan komposisi Saccharomyces cereviseae sebesar 16 gr menghasilkan kadar etanol sebesar 5,4\%, Pada komposisi Saccharomyces cereviseae 20 gr dihasilkan kadar etanol sebesar 5.3\%, Pada sampel komposisi Saccharomyces cereviseae 24 gr 
diperoleh kadar etanol sebesar 5.2\%, Pada sampel komposisi Saccharomyces cereviseae 28 gr didapatkan kadar alkohol sebesar 5.1\%, Pada sampel komposisi Saccharomyces cereviseae 32 gr dihasilkan kadar etanol sebesar 3,3\%. Pada Gambar 2 menunjukkan bahwa semakin besar komposisi Saccharomyces cereviseae maka semakin rendah kadar etanolnya karena semakin berkurangnya jumlah khamir sehingga antar enzim khamir saling berkompetisi untuk memenuhi kebutuhan makanannya untuk mendapatkan tenaga. Hal ini mulai berkurangnya kandungan glukosa dan nutrient pada substrat sehingga energi yang dihasilkan oleh Saccharomyces cereviseae semakin kecil dengan terbentuk senyawa-senyawa lain yang mengakibatkan hasil kadar etanol pun menjadi rendah. Nurisa Rachmawat, et.al (2019) menyebutkan bahwa alkohol teroksidasi oleh bakteri asam asetat menjadi asam asetat [10]. Aktivitas dalam proses fermentasi mengakibatkan peningkatan pada kadar etanol. Etanol akan terus berlangsung terurai menjadi asam asetat meskipun aktivitas fermentasi menurun.

Pada komposisi 32gr memiliki kadar etanol paling rendah karena Saccharomyces cerevisiae memasuki fase stasioner yaitu tidak optimal lagi untuk bekerja sehingga terjadi penurunan dari 5,1\% menjadi 3,3\%. Pada fase ini khamir mengalami kematian karena terjadi proses perubahan reaksi menjadi asam asetat yaitu produk samping dari proses fermentasi. Reaksi asam asetat yang dihasilkan akan menghasilkan reaksi lanjut dengan membentuk 3 lapisan yaitu protein, air dan etanol (teratas). Dalam reaksi ini bakteri membentuk film permukaan cairan, berikut reaksinya :

$\begin{array}{clll}\mathrm{CH}_{3} \mathrm{CH}_{2} \mathrm{OH} & \mathrm{CH}_{3} \mathrm{CHO} & \mathrm{CH}_{3} \mathrm{CH}(\mathrm{OH})_{3} & \mathrm{CH}_{3} \mathrm{COOH} \\ \text { Etanol } & \text { Asetaldehid } & \text { Asetaldhid hidrat } & \text { Asam Asetat }\end{array}$

Pada reaksi diatas merupakan reaksi yang terjadi saat penambahan sel khamir, sehingga terjadi pertumbuhan mikroorganisme.

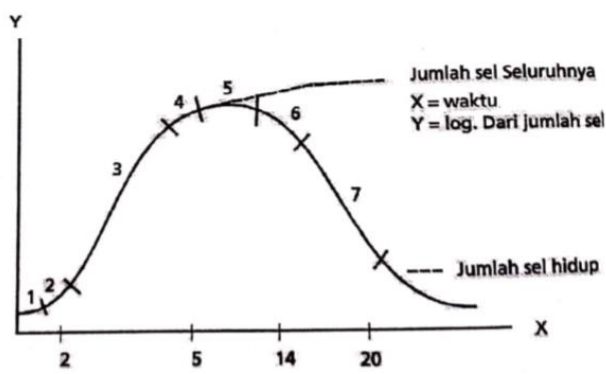

Gambar 3. Kurva Pertumbuhan Jasad Renik

Pada Grafik 3. menunjukkan bahwa pada zona 1_4 terlihat semakin besar jumlah khamir maka semakin tinggi pula kadar ethanol yang dihasilkan. Pada fase ini terjadi proses membelah diri yaitu perubahan substansi intraseluler selain itu terjadi perubahan kimiawi dan ukuran. Pada zona 1_4 ini bakteri mengalami adaptasi terhadap lingkungan sehingga belum terjadi etanol. Pada fase ini terjadi pada sample komposisi Saccharomyces cerevisiae atau khamir sebesar 8 gram.

Pada zona 4_5, terjadi pertumbuhan konstan dengan semakin besar jumlah khamir maka semakin konstan hasil kadar etanolnya, yang berarti laju pertumbuhan maksimum yang terjadi adalah konstan selama proses fermentasi. Hal ini terjadi karena adanya rantai molekul dari substrat yang masih panjang, sehingga membutuhkan energi besar untuk memecah substrat dari rantai molekul tersebut. molekul. Pada fase ini, khamir menghasilkan etanol paling banyak, keadaan ini terjadi pada komposisi Saccharomyces cerevisiae sebesar 12 gram hingga 28 gram.

Pada zona 5_7, konsumsi substrat telah mulai dipengaruhi oleh akumulasi toksin, terjadinya penumpukan toksin akibat penurunan nutrient sehingga terjadi 
kompetisi antar sel khamir untuk hidup dan tumbuh sehingga banyak yang mengalami kematian. Pada fase ini etanol yang dihasilkan menurun, keadaan ini terjadi pada komposisi 28 gram hingga komposisi 32 gram

\section{KESIMPULAN}

Kesimpulan dari penelitian tentang pengaruh jumlah khamir secara anaerob terhadap kualitas etanol dari tetes tebu (molases) yaitu adanya pengaruh jumlah khamir terhadap kualitas etanol. Kadar etanol tertinggi 5,6\% dihasilkan pada komposisi 12gram, sedangkan kadar etanol terendah 3,3\% dihasilkan pada komposisi komposisi 32gram.

\section{DAFTAR PUSTAKA}

[1] I. Kholiq, "Pemanfaatan Energi Alternatif sebagai Energi Terbarukan untuk Mendukung Subtitusi BBM," IPTEK, vol. 19, no. 2, pp. 75-90, 2015, [Online]. Available: https://ejur-

nal.itats.ac.id/iptek/article/download /12/12.

[2] P. K. Atmodjo, "Optimalisasi Gula Cair dan $\mathrm{pH}$ Medium untuk Fermentasi Alkohol dari Jus Curucuma xanthorihiza," Biota, vol. 2, no. 3, pp. 97-103, 2017, [Online]. Available:

https://ojs.uajy.ac.id/index.php/biot a/article/download/1885/1253.

[3] Fathorrahman, A. S. Selan, and S. P. A. Anggraini, "Proses Pembuatan Ethanol Semikontinyu melalui Rekayasa Alat Fermentor Fluidisasi," Buana Sains, vol. 12, no. 2, pp. 1-7,
2012, [Online]. Available: https://jurnal.unitri.ac.id/index.php/buanasains /article/download/126/128.

[4] S. P. A. Anggraini and S. Yuniningsih, "Pengaruh pH terhadap Kualitas Produk Etanol dari Molasses melalui Proses Fermentasi," Reka buana, vol. 2, no. 2, pp. 99-105, 2017, [Online]. Available:

https://jurnal.unitri.ac.id/index.php/ rekabuana/article/download/725/70 3.

[5] H. A. Darojati, "Prospek Pengembangan Teknologi Radiasi sebagai Perlakuan Pendahuluan Biomassa Lignoselulosa," J. FORUM Nukl., vol. 11, no. 2, 2017, [Online]. Available: http://jurnal.batan.go.id/index.php/j fn/article/view/5313.

[6] Y. T. F. Marpaung, P. Hutagaol, W. Limbong, and N. Kusnad, "Perkembangan Industri Gula Indonesia dan Urgensi Swasembada Gula Nasional," Indones. J. Agric. Econ., vol. 2, no. 1, 2011, [Online]. Available: https://me-

dia.neliti.com/media/publications/90 20-ID-perkembangan-industri-gulain-donesia-dan-urgensi-swasembadagu-la-nasional.pdf.

[7] M. Rijal, A. Rumbaru, and A. Mahulauw, "Pengaruh Konsentrasi Saccharomyces cereviceae Terhadap Produksi Bioetanol Berbahan Dasar Batang Jagung," J. Biol. Sci. Educ., vol. 8, no. 1, 2019, [Online]. Available: https://jurnal.iainambon.ac.id/index. $\mathrm{php/BS/article/download/847/587.}$

[8] Yurliasni and Y. Zakaria, "Kajian Penambahan Khamir Kluyveromyces lactis, Candida curiosa dan 
Brettanomyces custersii Asal Dadih terhadap Konsentrasi Asam-asam Amino, Lemak, Organik dan Karbohidrat Susu Kerbau Fermentasi (Dadih)," Bionatura-Jurnal Ilmu-ilmu Hayati dan Fis., vol. 15, no. 1, pp. 5459, 2013, [Online]. Available: https://media.neliti.com/media/publ ications/218490-none.pdf.

[9] D. H. Simanjuntak, Herpandi, and S. D. Lestari, "Karakteristik Kimia dan Aktivitas Antioksidan Kombucha dari Tumbuhan Apu-apu ( Pistia stratiotes ) Selama Fermentasi," J. Teknol. Has. Perikan., vol. 5, no. 2, pp. 123-133, 2016, [Online]. Available: https://me-

dia.neliti.com/media/publications/62 170-ID-karakteristik-kimia-dan-aktivitas-antiok.pdf.

[10] N. Rachmawati, F. A. Nurlaily, and B. D.Wijatniko,"Pengaruh Waktu Fermentasi dan Penambahan Konsen- trasi Inokulum (Acetobacter aceti) terhadap Kualitas Asam Cuka dari Buah Kersen (Muntingia calabura L)," Indones. J. Halal Sci., vol. 001, no. 01, pp. 12-17, 2019, [Online]. Available: http://ejournal.uin.uka.ac.id/saintek/IJHS/article /download/1648/1512uka.ac.id/saint ek/IJHS/article/download/1648/151 2. 